\title{
Kwestie przyrodnicze w Encyklice \\ Laudato si' Ojca Świętego Franciszka
}

\author{
Barbara Żarska \\ Wydział Ogrodnictwa, Biotechnologii i Architektury Krajobrazu \\ Szkoły Głównej Gospodarstwa Wiejskiego - SGGW w Warszawie, \\ Katedra Ochrony Środowiska, ul. Nowoursynowska 166, bud. 37, 02-787 Warszawa, barbara_zarska@sggw.pl
}

\begin{abstract}
Streszczenie
Encyklika Laudato si' Ojca Świętego Franciszka jest nowym dokumentem rangi światowej dotyczącym globalnego kryzysu środowiska i relacji "człowiek - środowisko". W artykule przedstawiono analizę treści encykliki pod względem sposobu ujęcia, argumentów i proponowanych działań na rzecz przyrody i przezwyciężenia kryzysu środowiska. Tezy zawarte w encyklice są spójne ze strategicznymi dokumentami, programami i prawem na poziomie krajowym, Unii Europejskiej i międzynarodowym. Ojciec Święty nadał jednak nieco inny kierunek podejmowanym działaniom w zakresie ochrony przyrody i doskonalenia relacji „człowiek - środowisko”. Papież Franciszek wskazał na głębokie powiązanie kryzysu ekologicznego z kryzysem społecznym. Nazwał kryzys społeczno-ekologicznym. Encyklika Laudato si' jest dokumentem o znaczeniu światowym w walce z tym kryzysem.
\end{abstract}

\section{Slowa kluczowe}

encyklika Laudato si', globalny kryzys środowiska przyrodniczego, kryzys społeczno-ekologiczny, relacja "człowiek - środowisko"

\section{Wprowadzenie}

W sytuacji konieczności rozwiązywania pilnych problemów wynikających z globalnego kryzysu środowiska oraz podejmowania zintegrowanych działań w tym zakresie na poziomie globalnym, kontynentalnym i krajowym pojawił się papieski dokument rangi światowej, traktujący o tych zagadnieniach: encyklika Laudato si.' W trosce o wspólny dom (2015).

Celem artykułu jest analiza sposobu ujęcia, argumentów i propozycji działań na rzecz ochrony przyrody i środowiska w encyklice Laudato si' oraz wskazanie ewentualnych korelacji treści tego dzieła z wybranymi strategicznymi dokumentami (programami, raportami) i aktami prawnymi na poziomie krajowym, Unii Europejskiej i międzynarodowym.

\section{Kwestie stanu środowiska} przyrodniczego, relacji "czlowiek środowisko przyrodnicze" i koniecznych działań w tym zakresie sformułowane przez papieża Franciszka w encyklice Laudato si'

Ojciec Święty Franciszek poruszył w encyklice Laudato si' liczne kwestie przyrodnicze bezpośrednio odnoszące się do stanu środowiska, ochrony przyrody oraz relacji 
„człowiek - środowisko przyrodnicze”, „człowiek - przyroda”. Oto niektóre z tych kwestii.

1. Personifikacja Ziemi i poszczególnych bytów przyrodniczych (innych niż człowiek). Ojciec Święty nazwał inne byty przyrodnicze „braćmi i siostrami”, a Ziemię - „matką” (Mother Earth). Można to interpretować jako podniesienie ich do wyższej rangi, zbliżonej do rangi człowieka. „Matka” protestuje i cierpi z powodu „zła, jakie jej wyrządzamy nieodpowiedzialnym wykorzystywaniem i rabunkową eksploatacją" (LS: 2$)^{1}$. Są wykazane przyczyny złej kondycji innych bytów przyrodniczych i całej Ziemi, określone ogólnie jako szkodliwa działalność człowieka. „Objawy choroby” środowiska są dostrzegane w glebie, wodzie, powietrzu i istotach żywych.

2. Człowiek potrzebuje środowiska przyrodniczego do życia (LS: 2, 43). Papież Franciszek wskazał na ścisły związek człowieka z przyrodą. Czy traktuje człowieka jako część przyrody? Podkreślił, że ludzie „są z prochu Ziemi”, a ciało człowieka zbudowane jest z pierwiastków naszej planety. Papież Franciszek odniósł się do usług ekosystemowych (usług, jakie świadczy środowisko na rzecz człowieka; ecosystem services; DEFRA, 2007), przypominając m.in. o tym, że powietrze pozwala nam oddychać, a woda poi i obmywa. Podkreślił, że w obliczu globalnej degradacji środowiska wszystkie osoby zamieszkujące Ziemię koniecznie muszą się zmobilizować do działania na rzecz „naszego wspólnego domu".

3. Konieczność zwrócenia pilnej uwagi i skierowania działań na rozwiązanie problemów społeczno-środowiskowych w miastach. Ojciec Święty podkreślił, że wyjątkowo niezdrowe warunki do życia człowieka panują w miastach będących wielkimi skupiskami populacji ludzkiej. Wskazuje na niekontrolowany

1 Na oznaczenie encykliki Laudato si' będzie stosowany skrót LS. w wystarczającym stopniu i nadmierny rozwój miast, w których zagrożenia środowiska szczególnie się kumulują (m.in. zanieczyszczenia, chaos, problemy transportowe, skażenie wizualne, hałas), a przy tym często brak w nich dostatecznej ilości terenów zieleni dostępnych dla wszystkich (LS: 45). Papież wskazał, że nie można asfaltować, betonować, zabudowywać wszystkiego. Miasta zużywają również dużo wody - deficytowego zasobu przyrodniczego na wielu obszarach (LS: 44). Są to bezpośrednie odniesienia i zalecenia działań prośrodowiskowych, analogiczne do tych zalecanych w strategiach Unii Europejskiej i światowych raportach o stanie środowiska (Milenijna Ocena Ekosystemów, 2007; Nasze ubezpieczenie na życie..., 2011; Living Planet Report, 2014; EEA 2015), aby kształtować zieloną infrastrukturę, rozwijać tereny zieleni, zwiększać powierzchnie biologicznie czynne oraz prowadzić racjonalne gospodarowanie wodą.

4. Kontynuacja i rozwój myśli prośrodowiskowych głoszonych przez innych papieży i filozofów. Papież Franciszek odwołuje się do słów innych papieży i myślicieli (LS: 4-16), np.:

-Paweł VI: kryzys środowiska jest spowodowany nierozważnym wykorzystywaniem przyrody przez człowieka; kryzys ten prowadzi do zniszczenia środowiska, a człowiek sam padnie ofiarą tej degradacji;

-Jan Paweł II (1979, 1987, 1991): człowiek dostrzega środowisko tylko w aspekcie „użycia i zużycia”; zachęcał do globalnego nawrócenia ekologicznego; twierdził, że zniszczenie środowiska równa się zniszczeniu środowiska ludzkiego; rozwój człowieka ma charakter moralny i oznacza nie tylko poszanowanie osoby ludzkiej, ale też powinien być ukierunkowany na świat przyrody - na każdy byt przyrodniczy;

-Benedykt XVI (2007): trzeba korygować modele rozwoju w aspekcie 
poszanowania środowiska; do tzw. „księgi natury” zaliczył środowisko wraz z człowiekiem;

- Patriarcha Bartłomiej: niszczenie środowiska jest grzechem, „zbrodnia przeciw naturze jest zbrodnią przeciw nam samym i grzechem przeciw Bogu";

-Św. Franciszek: należy wykazywać wrażliwość względem bytów przyrodniczych; uważany za patrona ekologii integralnej.

Przytoczone myśli i poglądy są dowodem, że ich autorzy rozumieli bardzo ścisły związek i zależność między człowiekiem i środowiskiem przyrodniczym, a Ojciec Święty Franciszek podziela ich poglądy pod tym względem.

5. Wezwanie do wspólnej (globalnej) walki z przyczynami i skutkami degradacji środowiska, ze szczególnym uwzględnieniem obszarów, gdzie żyją ludzie najubożsi. Zdaniem papieża Franciszka (LS: 13) na ogromną wdzięczność zasługują ci, którzy walczą z dramatycznymi skutkami degradacji środowiska, zwłaszcza w życiu najuboższych. Ojciec Święty sformułował postulat wzmożenia dialogu dotyczącego sposobu, w jaki mamy budować przyszłość Ziemi; wszyscy muszą ze sobą współpracować, każdy ze swoją kulturą, możliwościami i dorobkiem. Wyraził poparcie dla globalnego ruchu ekologicznego. Zaproponował wdrożenie takiej ekologii, która łączyłaby pozycję człowieka i jego relacje z otaczającą rzeczywistością (LS: 15).

6. Dostrzeżenie szansy lepszego zrozumienia potrzeby ochrony środowiska, tym samym zwiększenia świadomości ekologicznej społeczeństw. W obecnej trudnej sytuacji globalnego kryzysu środowiska Ojciec Święty dostrzegł też pozytywny aspekt - szansę w tym, że społeczeństwa wkraczają w etap zwiększonej świadomości ekologicznej (LS: 19). Wzmaga się wrażliwość ludzi na niszczenie środowiska i rośnie troska o przyrodę. Zdaniem Ojca Świętego trzeba to przełożyć na bardziej efektywne działanie.

7. Wskazanie przyrody jako wzorca rozwoju zrównoważonego. Ojciec Święty wskazał, że funkcjonowanie naturalnych ekosystemów powinno być wzorem do optymalnego użytkowania zasobów (LS: 22). Emisja $\mathrm{CO}_{2}$ powinna zostać zmniejszona poprzez zastępowanie paliw kopalnych i rozwijanie energetyki opartej na odnawialnych źródłach (OZE). Należy zwiększać dostęp do OZE, rozwijać technologie gromadzenia energii, sposoby budowy i modernizacji budynków energooszczędnych (LS: 26) - to powinno być powszechne zdaniem Ojca Świętego. W encyklice zawarta jest zatem promocja zielonej energii i promocja oszczędnego użytkowania zasobów, w tym paliw kopalnych. Wpisuje się to $\mathrm{w}$ strategię zmian $\mathrm{w}$ energetyce $\mathrm{w}$ Unii Europejskiej (EEA 2015).

8. Wezwanie do ograniczenia konsumpcji i zmiany stylu życia głównie w krajach rozwiniętych. Ojciec Święty zwrócił uwagę, że nie jest możliwe utrzymanie obecnego poziomu konsumpcji w krajach rozwiniętych. W wielu regionach świata nie ma dostępu do wody pitnej (i dostępu do odpowiedniej jakości wody) dla dużej części ludności świata (najbiedniejszych), liczonej już w miliardach (LS: 27-31). Brakuje żywności. Zasoby przyrody są właściwie jedyną podstawą gospodarowania w krajach najbiedniejszych (rybołówstwo, rolnictwo, leśnictwo; w zasadzie brak alternatywy; (LS: 25).

9. Spadek różnorodności biologicznej jako ważny problem, wymagający podjęcia intensywnych działań naprawczych. Zdaniem Ojca Świętego zbyt małą wagę przykłada się do ubytku różnorodności biologicznej, a tym samym do degradacji usług ekosystemowych. Kiedy zmniejsza się różnorodność biologiczna, maleją możliwości wyżywienia ludności świata, gospodarowania opartego na zasobach przyrody żywej, leczenia 
i korzystania $\mathrm{z}$ innych usług środowiskowych. Wymieranie gatunków z powodu działalności człowieka to bardzo niepokojący fakt. „Nie mamy do tego prawa" - stwierdził Ojciec Święty (LS: 33). Zwrócił uwagę na nieodtwarzalność wymarłych gatunków. Zauważył, że często powstaje „błędne koło”: interwencja człowieka w celu rozwiązania pewnych problemów prowadzi do pogorszenia sytuacji lub powstania nowych problemów. Ojciec Święty wezwał do zwiększenia nacisku na staranność sporządzania ocen oddziaływania na środowisko (procedura OOŚ - instrument ochrony środowiska o charakterze prewencyjnym) programów, planów i przedsięwzięć - w zakresie wpływu na różnorodność biologiczną. W dotychczasowej procedurze OOŚ zazwyczaj dokładnie badany jest wpływ projektowanego programu czy przedsięwzięcia na glebę, wodę, powietrze, a mniej - na różnorodność biologiczną (LS: 34). To bardzo cenne, że Ojciec Święty odnosi się wprost do jednego z najważniejszych instrumentów ochrony środowiska, podnosząc jego rangę swym autorytetem. Ojciec Święty zwrócił też uwagę na degradację poszczególnych typów ekosystemów / krajobrazów. Następuje ciągła utrata lasów tropikalnych. Konieczna jest do osiągnięcia w tym zakresie „trudna równowaga”, co jest rolą rządów i organizacji międzynarodowych, a ponadto wymaga stworzenia społeczeństwa obywatelskiego - aby rządy i społeczeństwa wypełniały swój obowiązek ochrony środowiska (LS: 38). Utrata lasów naturalnych (przekształcanie ich w uprawy leśne lub inne rodzaje zagospodarowania terenu), zamiana bagien na użytki rolne, zanikanie lasów przybrzeżnych - to bardzo niepokojące zmiany (LS: 39). Zagrożenia różnorodności biologicznej oceanów i innych wód, polegające na zanieczyszczeniu i nadmiernym eksploatowaniu (ponad zdolność naturalnego odtwarzania) ich zasobów żywych - to niebezpieczeństwo dla licznych społeczności, które się z tego utrzymują i nie mają innej możliwości rozwoju. Postępuje niszczenie raf koralowych (bardzo bogatych gatunkowo; LS: 40-41). Zanieczyszczenie mórz w dużej mierze pochodzi z lądów (z obszarów zlewni), z których płyną ładunki zanieczyszczeń. Sprzyja temu złe zagospodarowanie terenów, wylesianie, nawożenie obszarów rolnych. Ojciec Święty zwrócił też uwagę na konieczność zaniechania degradujących metod połowu (np. tych z użyciem cyjanku i dynamitu) (LS: 41).

10. Krótkowzroczność w zarządzaniu i gospodarowaniu - szkodliwa dla społeczności i środowiska przyrodniczego. Zdaniem Ojca Świętego w zarządzaniu i gospodarowaniu patrzymy przeważnie tylko na względy doraźne, głównie ekonomiczne (LS: 36), podczas gdy koszty utraty różnorodności biologicznej są znacznie wyższe i długofalowe. Przyszłe pokolenia zapłacą ogromną cenę za degradację środowiska. Rządy mają obowiązek ochrony środowiska. Znaczenie organizacji pozarządowych, międzynarodowych i organizacji społeczeństwa obywatelskiego jest nie do przecenienia: ich wysiłek skłania rządy do wypełnienia obowiązków (LS: 36, 38).

11. Zachęcanie do większego inwestowania w badania naukowe. Ojciec Święty wskazał na konieczność rozwijania badań naukowych, aby lepiej rozumieć działanie ekosystemów, być świadomym różnorodności i potrzeb bytów przyrodniczych (LS: 42). Wszystkie istoty żywe potrzebują siebie nawzajem, dlatego każdy kraj powinien pogłębiać wiedzę na ich temat, m.in. sporządzając inwentaryzacje gatunków, programy i strategie ochrony; należy zwłaszcza zważać na gatunki i ekosystemy zagrożone wyginięciem.

12. Konieczność ochrony przyrody dla jej piękna jako jeden $\mathrm{z}$ ważnych aspektów 
i argumentów. Nie możemy zastąpić piękna przyrody innym pięknem stworzonym przez człowieka (LS: 34). Odtworzenie piękna przyrody zniszczonej przez człowieka jest tylko częściowo możliwe. To stwierdzenie Ojca Świętego jest spójne z opinią opartą na przesłankach naukowych, że Człowiek mimo ogromnej wiedzy i postępu technologicznego nie jest w stanie odtworzyć przyrody w pełni (Żarska, 2010). Piękno przyrody jest potrzebne człowiekowi do realizacji jego różnorodnych potrzeb, w tym estetycznych i sztuki. Przyroda zawsze stanowiła inspirację dla ludzi do tworzenia nowego dzieła, także dzieła sztuki. Człowiek tworzący sztukę jest uwarunkowany przyrodniczo i kulturowo. Wpływ przyrody na sztukę tworzoną przez człowieka jest też rodzajem usługi ekosystemowej. Przyroda stanowi dla człowieka tworzącego dzieło sztuki inspirację świadomą lub podświadomą. Można mówić o sztuce przyrody: harmonijność krajobrazów naturalnych (jako „wrodzona” ich cecha), różnorodność bytów przyrodniczych, różnorodność form i kolorów, możliwość tworzenia kompozycji od najprostszych do bardzo złożonych, możliwość tworzenia krajobrazów nawet najbardziej abstrakcyjnych i nieoczekiwanych, zaskakujących wobec permanentnej harmonijności kompozycji (Żarska, 2010, 2011). To fenomen przyrody, który warunkuje człowieka w jego działalności.

13. Zajęcie stanowiska w odwiecznej dyskusji nad tym, czy człowiek ma prawo absolutnie panować nad Ziemią. Ojciec Święty wskazał, że Ziemia istniała wcześniej niż my, niż została nam dana do zagospodarowania (LS: 67, 68). Zwrócił uwagę, że nie można wnioskować absolutnego panowania człowieka nad innymi istotami. Należy szanować delikatną równowagę między bytami świata, w tym człowiekiem. Ojciec Święty podkreślił, że błędne jest myślenie, iż istoty żywe to przedmioty (LS: 82). Każde stworzenie ma swoją funkcję i jest niezbędne. Człowiek jest tak ściśle powiązany $\mathrm{z}$ otaczającym światem, że „pustynnienie ziemi jest niejako chorobą dotykającą wszystkich", a nad wymierającymi gatunkami możemy ubolewać ,jak nad swoistym okaleczeniem" (LS: 89). Okrucieństwo wobec innych stworzeń zawsze przekłada się na sposób traktowania ludzi (LS: 92). Stanowisko to jest spójne z poglądami takich filozofów, jak: Montaigne, Artur Schopenhauer, Humphrey Primmatt, czy prekursorzy nowoczesnej etyki ekologicznej: Mahatma Gandhi, Aldo Leopold i Albert Schweitzer (Dobrzański i in. 2009). Zdaniem Ojca Świętego środowisko jest rodzajem dobra wspólnego pokoleń, „którego owoce powinny służyć wszystkim”. Tak też uważał Jan Paweł II (1991), na którego słowa powołuje się papież Franciszek. Wprawdzie Ojciec Święty Franciszek stwierdził, że nie oznacza to zrównania wszystkich istot żywych i odbierania człowiekowi szczególnej wartości (LS: 9o), jednak treści te świadczą, że środowisko przyrodnicze ma ważnego i silnego sojusznika w osobie papieża i Kościoła.

\section{Wybrane międzynarodowe, unijne i krajowe dokumenty strategiczne, raporty i akty prawne dotyczące ochrony środowiska o treściach harmonizujących z Encykliką Laudato si'}

Treści, które Ojciec Święty umieścił w encyklice Laudato si', są skorelowane z zawartością dokumentów, raportów i aktów prawnych zarówno międzynarodowych i Unii Europejskiej, jak i krajowych. Oto przykłady dokumentów, raportów i aktów prawnych harmonizujących z treścią encykliki papieża Franciszka:

- Nasze ubezpieczenie na życie i nasz kapitał naturalny - unijna strategia ochrony różnorodności biologicznej na okres do 2020. [Our life insurance, our natural capital: an EU biodiversity 
strategy to 2020]. Komunikat Komisji do Parlamentu Europejskiego, Rady, Europejskiego Komitetu Ekonomiczno-Społecznego i Komitetu Regionów $\operatorname{KOM}(2011) 244$ wersja ostateczna. Bruksela, 3.5.2011

- EEA 2015. Środowisko Europy 2015. Stan i prognozy. Synteza. Kopenhaga: Europejska Agencja Ochrony Środowiska

- Living Planet Report, 2014. WWF, Londyńskie Towarzystwo Zoologiczne, Global Footprint Network

- Milenijna Ocena Ekosystemów, 20062007 [The UN Millennium Ecosystem Assessment, 2006-2007]. The House of Commons Environmental Audit Committee, 2007

- Dyrektywa Rady 79/409/EWG z dnia 2 kwietnia 1979 roku w sprawie ochrony dzikich ptaków, zastąpiona ujednoliconą wersją - Dyrektywą Parlamentu Europejskiego i Rady 2009/147/WE z dnia 30 listopada 2009 roku w sprawie ochrony dzikiego ptactwa (ze zm.)

- Dyrektywa Rady 92/43/EEC z dnia 21 maja 1992 roku w sprawie ochrony siedlisk przyrodniczych oraz dzikiej fauny i flory (ze zm.)

- Communication from the Commission to the European Parliament, the Council, the Economic and Social Committee and Committee of the Regions. Green Infrastructure (GI) - Enhancing Europe's Natural Capital [SWD(2013) 155 final]. Brussels, 6.5.2013, COM (2013) 249 final

- Program Rozwoju Obszarów Wiejskich na lata 2014-2020 (PROW 2014-2020). Ministerstwo Rolnictwa i Rozwoju Wsi

- W stronę zielonej gospodarki. Drogi do zrównoważonego rozwoju i zwalczania biedy [Towards Green Economy. Pathways to Sustainable Development and Poverty Eradication] [Green Economy Report] UNEP, 2011

- Polityka ekologiczna państwa - ustanawiana co 4 lata (Ministerstwo Środowiska)
- Strategiczny Plan Adaptacji dla sektorów i obszarów wrażliwych na zmiany klimatu do roku $2020 \mathrm{z}$ perspektywą do roku 20130 - SPA 2020 (Ministerstwo Środowiska)

- Programy ochrony gatunków zagrożonych wyginięciem (Ministerstwo Środowiska)

Diagnoza postawiona przez Ojca Świętego w encyklice Laudato si' jest zgodna z oceną stanu zawartą w wyżej wymienionych dokumentach. Proponowane działania naprawcze są również zbieżne. Jednakże papież Franciszek idzie krok dalej, stwierdzając, że degradacja człowieka i społeczeństwa jest powiązana z degradacją środowiska naturalnego, a podejście ekologiczne powinno być jednocześnie podejściem społecznym. Zdaniem Ojca Świętego konieczne jest włączenie sprawiedliwości społecznej w dyskurs o środowisku. Co więcej, degradacja środowiska jest powiązana z degradacją etyczną. W zasadzie należy mówić o kryzysie społeczno-ekologicznym (LS: 139). Rozwija się ekologia „pozorna”, która bagatelizuje trudną sytuację środowiskowo-społeczną, a tak nie powinno być (LS: 48-50, 56, 59). Ojciec Święty zaapelował do rządów i społeczeństw o stworzenie wysokiej kultury ekologicznej, która winna się przejawiać w odpowiedniej polityce, programach, doskonaleniu prawa, myślach i stylu życia (LS: 111).

Encyklika Laudato si' ma znaczenie światowe. Jej treści, ranga i spodziewane oddziaływanie na narody i rządy upoważniają do nazwania encykliki dokumentem przełomowym w walce z kryzysem społeczno-ekologicznym świata (przełom w skuteczności działań).

\section{Wnioski}

Występuje duża korelacja między tezami i działaniami prośrodowiskowymi proponowanymi przez papieża Franciszka w encyklice Laudato si' a polityką, dokumentami strategicznymi, raportami i prawem w zakresie ochrony środowiska na poziomie krajowym, Unii Europejskiej i światowym.

Koszty degradacji środowiska / przyrody, a co za tym idzie degradacji usług 
ekosystemowych, poniosą przede wszystkim i w największym stopniu społeczności krajów rozwijających się, ubogich; dotychczasowe programy i inne działania globalne powinny być mocniej na ten problem ukierunkowane niż obecnie (wymagają wzmocnienia i przeniesienia akcentów). Kryzys ekologiczny jest ściśle powiązany z kryzysem społecznym. W istocie mamy do czynienia z kryzysem społeczno-ekologicznym.

Rządy i społeczeństwa uzyskały potężnego sojusznika w osobie papieża i społeczności Kościoła w staraniach o wysoką jakość stanu środowiska przyrodniczego i dobre traktowanie istot żywych. Encyklika Laudato si' jest dokumentem o charakterze fundamentalnym w walce z kryzysem społeczno-ekologicznym w skali świata.

Człowiek pomimo całej swej wyjątkowości jest jednym z bytów przyrodniczych. Środowisko przyrodnicze jest mu potrzebne do życia.

Personifikacja bytów przyrody przez Ojca Świętego upoważnia do interpretacji, że zostały podniesione do wyższej rangi, zbliżonej do rangi człowieka.

Wzmacnianie związku człowieka z resztą przyrody to warunek długoterminowego przetrwania świata jako całości, wraz z człowiekiem.

\section{Bibliografia}

Benedykt XVI. 2007. Przemówienie do korpusu dyplomatycznego, 8 stycznia 2007: AAS 99 (2007), 73.

Communication from the Commission to the $\mathrm{Eu}$ ropean Parliament, the Council, the Economic and Social Committee and Committee of the Regions. Green Infrastructure (GI) - Enhancing Europe's Natural Capital [SWD(2013) 155 final]. Brussels, 6.5.2013, COM (2013) 249 final.

DEFRA. 2007. An Introductory Guide to Valuing Ecosystem Services, 1-214. London: Department for Environment, Food and Rural Affairs (DEFRA).

Dobrzański G., Dobrzańska B.M., Kiełczewski D.. 2009. Ochrona środowiska przyrodniczego. Białystok: Wyd. Ekonomia i Środowisko.

Dyrektywa Rady 79/409/EWG z dnia 2 kwietnia 1979 roku w sprawie ochrony dzikich ptaków, zastąpiona ujednoliconą wersją - Dyrektywą
Parlamentu Europejskiego i Rady 2009/147/WE z dnia 30 listopada 2009 roku w sprawie ochrony dzikiego ptactwa (ze zm.).

Dyrektywa Rady 92/43/EEC z dnia 21 maja 1992 roku w sprawie ochrony siedlisk przyrodniczych oraz dzikiej fauny i flory (ze zm.).

EEA 2015. Srodowisko Europy 2015. Stan i prognozy. Synteza. Kopenhaga: Europejska Agencja Ochrony Środowiska (http://www.eea.europa.eu, dostęp 10.02.2016).

Franciszek (papież). 2015. Encyklika Laudato si'. W trosce o wspólny dom, Kraków: Wydawnictwo M. Jan Paweł II. 1979. Encyklika Redemptor hominis, 4 marca 1979, 15: AAS 71 (1979), 287.

Jan Paweł II. 1987. Encyklika Sollicitudo rei socialis, 30 grudnia 1987, 34: AAS 80 (1988), 559.

Jan Paweł II. 1991. Encyklika Centesimus annus, 1 maja 1991, 31: AAS 83 (1991), 831.

Living Planet Report 2014. WWF, Londyńskie Towarzystwo Zoologiczne, Global Footprint Network (www.wwfpl.panda.org, dostęp 2.09.2015).

Nasze ubezpieczenie na życie i nasz kapitał naturalny - unijna strategia ochrony różnorodności biologicznej na okres do 2020. [Our life insurance, our natural capital: an EU biodiversity strategy to 2020]. Komunikat Komisji do Parlamentu Europejskiego, Rady, Europejskiego Komitetu Ekonomiczno-Społecznego i Komitetu Regionów KOM(2011) 244 wersja ostateczna. Bruksela, 3.5.2011 (http:// ec.europa.eu, dostęp 28.06.2016).

Milenijna Ocena Ekosystemów, 2006-2007 [The UN Millennium Ecosystem Assessment, 2006-2007]. The House of Commons Environmental Audit Committee, 2007 (www.publications,parliament. uk, dostęp 2.09.2015).

Program Rozwoju Obszarów Wiejskich na lata 2014-2020 (PROW 2014-2020). Skrócona wersja programu. Ministerstwo Rolnictwa i Rozwoju Wsi (www.minrol.gov.pl, dostęp 14.11.2015).

Strategiczny Plan Adaptacji dla sektorów i obszarów wrażliwych na zmiany klimatu do roku 2020 z perspektywą do roku 20130 - SPA 2020 (www. mos.gov.pl, dostęp 12.02.2016).

W stronę zielonej gospodarki. Drogi do zrównoważonego rozwoju i zwalczania biedy [Towards Green Economy. Pathways to Sustainable Development and Poverty Eradication] [Green Economy Report] UNEP, 2011 (www.unep.org/greeneconomy, dostęp 16.08.2015). 
Żarska B. 2011. Ochrona krajobrazu. Warszawa: Wydawnictwo SGGW.

Żarska B. 2010. Postawa twórcza wobec krajobrazu wynikająca z ochrony przyrody i środowiska.
W J. Skalski (red.). Horyzonty architektury krajobrazu. Warsztaty, 55-56. Warszawa: Wydawnictwo SGGW.

\section{Issues Dedicated to Nature in the Encyclical Letter Laudato Si' of the Holy Father Francis}

\section{Summary}

The Laudato Si' encyclical of the Holy Father Francis is a recent document addressing the issue of the global environmental crisis and as well as the man - environment relationship. The present paper provides an analysis of the Encyclical's content with respect to the manners of recognizing the crisis, arguments for nature protection and proposed activities aimed at overcoming the environmental crisis. The theses contained in the Encyclical are consistent with strategic documents, programmes and laws at the national level, the European Union and international level. The Holy Father, however, gave a slightly different direction to activities undertaken in the area of nature conservation and improvement of the man - environment relationship. Pope Francis pointed to the deep dependence between the ecological crisis and the social crisis. He pointed to the socio-ecological nature of this crisis. The Laudato Si' encyclical is a document of worldwide importance in the fight against the socio-ecological crisis.

\section{Key words}

encyclical Laudato Si', global environmental crisis, socio-ecological crisis, the man-environment relationship 